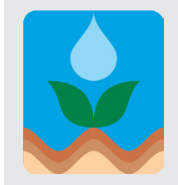

\author{
Revista Brasileira de Engenharia Agrícola e Ambiental \\ v.18, n.11, p.1149-1156, 2014 \\ Campina Grande, PB, UAEA/UFCG - http://www.agriambi.com.br \\ Protocolo 349.13 - 29/10/2013 • Aprovado em 13/06/2014
}

\title{
New agroclimatic approach for soybean sowing dates recommendation: A case study
}

\author{
Rafael Battisti ${ }^{1} \&$ Paulo C. Sentelhas ${ }^{2}$ \\ ${ }^{1}$ Department of Biosystems Engineering, University of São Paulo - ESALQ. Piracicaba, São Paulo, Brazil. E-mail: r.battisti@hotmail.com (Corresponding author) \\ ${ }^{2}$ Department of Biosystems Engineering, University of São Paulo - ESALQ, Piracicaba, São Paulo, Brazil. E-mail: pcsentel.esalq@usp.br
}

Key words:

Glycine max

climatic risk

crop zoning

agrometeorological model

production cost

\begin{abstract}
A B S T R A C T
The objective of this study was to introduce a new approach to recommend sowing dates for soybean crop in Brazil, considering the climatic conditions and crop yield. The first step was to define the periods when air temperature is smaller than $40{ }^{\circ} \mathrm{C}$ and greater than $1{ }^{\circ} \mathrm{C}$ in at least $80 \%$ of the years, and with at least $60 \%$ of relative crop evapotranspiration during the establishment phase in more than $50 \%$ of the years. The actual yield of crop was estimated by FAO Agroecological zone model for the suitable sowing dates. Based on that, when actual yield overcome the production cost in more than $80 \%$ of years and mean air temperature along the cycle is between 20 and $30^{\circ} \mathrm{C}$, the sowing date is classified as suitable, but if actual yield overcome the production cost only between 60 and $80 \%$ of the years or mean air temperature is not between 20 and $30^{\circ} \mathrm{C}$, the date is classified as marginal. Sowing dates are considered as unsuitable if actual crop yield overcome the production cost in less than $60 \%$ of the years. The new approach was applied, as case studies, for Cruz Alta, RS, Jataí, GO, and Balsas, MA, in order to compare it with the agroclimatic zoning approach presently used in Brazil. The new procedures can generate more accurate information to support sowing dates recommendation for soybean, minimizing yield losses from climatic risk.
\end{abstract}

Palavras-chave:

Glycine max

risco climático

zoneamento agrícola

modelo agrometeorológico

custo de produção

\section{Nova abordagem para recomendação de datas de semeadura na cultura da soja: Estudo de caso}

\begin{abstract}
R E S U M O
O objetivo deste trabalho foi apresentar uma nova metodologia para a recomendação das datas de semeadura para a cultura da soja no Brasil, considerando-se as condições climáticas e a produtividade. Definem-se, primeiro, as datas de semeadura em que não há ocorrência de temperatura do ar acima de $40{ }^{\circ} \mathrm{C}$ ou abaixo de $1{ }^{\circ} \mathrm{C}$ em pelo menos $80 \%$ dos anos e com disponibilidade maior que $60 \%$ da demanda hídrica da cultura na fase de estabelecimento em mais de $50 \%$ dos anos. Para as datas aptas foi estimada a produtividade da cultura por meio do modelo da zona agroecológica FAO. Se a produtividade superar o custo de produção em mais de $80 \%$ dos anos e a temperatura média do ar durante o ciclo da cultura for entre 20 e $30^{\circ} \mathrm{C}$, a data é classificada apta e marginal quando a produtividade estimada supera o custo de produção entre 60 e $80 \%$ dos anos ou a temperatura média não está entre 20 e $30^{\circ} \mathrm{C}$. Se esses níveis probabilísticos não são alcançados a data de semeadura é classificada inapta. Como estudo de casos, a metodologia foi aplicada para as localidades de Cruz Alta (RS), Jatai (GO) e Balsas (MA) de modo a ser comparada com a metodologia do zoneamento agrícola atualmente em uso no Brasil. Com esses procedimentos propostos para recomendar as datas de semeadura da soja é possível gerar informações mais acuradas, minimizando o risco climático para a produção desta cultura.
\end{abstract}

\section{INTRODUCTION}

Crop yield is mainly influenced by climatic conditions throughout the growing season, especially when the crops are cultivated under rainfed conditions. In Brazil, the soybean yield gaps are caused mainly by droughts. In 2011/2012 crop season, soybean had an average yield losses of 44,29 and 10\%, respectively, in the states of Rio Grande do Sul, Paraná and Mato Grosso do Sul (CONAB, 2013), which were caused by the reduction in rainfall in southern Brazil due to a "La Niña" event.

The yield gaps can be reduced with better crop management, which include the sowing in the best dates. Sowing dates influence soybean growth stages, due to variation in photoperiod (Han et al., 2006; Kumudini et al., 2007), air temperature (Chen \& Wiatrak, 2010), and rainfall distribution and amount during the crop cycle (Hu \& Wiatrak, 2012). In São Domingos, SC, Meotti et al. (2012) observed that $77 \%$ of soybean yield variability was associate with the climate conditions induced by the sowing dates.

Therefore, sowing soybean in the best dates offer the best climatic conditions to obtain high grain yield. In Nebraska, EUA, Bastidas et al. (2008) showed that there were yield reductions of 17 and $43 \mathrm{~kg} \mathrm{ha}^{-1} \mathrm{~d}^{-1}$, respectively in 2003 and 2004 seasons, when soybean was sown after $1^{\text {st }}$ May. In 
Dourados, MS, Brazil, Fietz \& Rangel (2008) identified that November is the best month for soybean sowing due to the increase in photoperiod and decrease of water deficit, when compared to other dates.

Environmental conditions can change the yield in the same sowing date in different years, therefore, just one field experiment can not bring conclusive results for choosing the best sowing date (Egli \& Cornelius, 2009). This problem can be solved by the use of historical climatic series applied to crop models for estimating yield in such a way that the choice of the best sowing date is based on a probabilistic level. Similar method has been used by several authors to define sowing dates for different crops and places (Farias et al., 2001; Anapalli et al., 2005; Soler et al., 2010; Battisti et al., 2013).

In Brazil, Minister of Agriculture, Livestock and Food Supply (MAPA) implemented the agroclimatic risk zoning to define the suitable sowing dates for several crops (MAPA, 2012). Soybean sowing dates are recommended based on the relative evapotranspiration during the flowering/grain filling phases. This kind of zoning does not consider water availability during other growth stages, the potential yield, extreme temperature conditions, water availability for sowing, cultivars characteristics, as drought tolerance, actual yield and economic aspects.

Based on that, the aims of this study were to introduce a new approach to recommend the best soybean sowing dates in Brazil based on climate variability, crop yield and net income, assisting farmers in their agricultural planning, and to apply this methodology to three soybean producing regions, as case studies, and compare it with agroclimatic risk zoning presently used in Brazil.

\section{Material ANd Methods}

The new approach for recommending the best sowing dates for soybean crop considers maximum and minimum air temperature, water availability at the sowing, estimated actual yield and its probability of occurrence, production cost and the soybean price, mean air temperature and the interaction among these factors to define sowing dates as suitable, marginal or unsuitable. The six steps for defining sowing dates as suitable, marginal or unsuitable are described below:

Step 1 - Maximum and minimum air temperature: Air temperature is not favorable for soybean when maximum air temperature is greater than $40^{\circ} \mathrm{C}$ (Farias et al., 2009) and minimum air temperature is below $1{ }^{\circ} \mathrm{C}$ (Rosenberg et al., 1983). High temperature affects growing rate and reduces the capacity of pod retention during flowering/grain filling phases and reduces plant population during establishment phase. Minimum air temperature below $1{ }^{\circ} \mathrm{C}$ is considered critical for soybean crop during all crop phases, since it represents frost events. Sowing dates are considered as suitable in the absence of extreme temperatures in at least $80 \%$ of the years during all crop phases. This probability should be based on a daily historical data series with at least 15 years, as is considered in agroclimatic risk zoning (MAPA, 2012). Sowing dates are classified as unsuitable when extreme air temperature events are greater than $20 \%$ of the years.

Step 2 - Water availability at the sowing: For the soybean sowing the available soil water should be high enough to allow seed germination and plant establishment. In the Midwest and North regions of Brazil the winter is normally dry and the sowing needs to wait for the first rains to be started. Therefore, soybean sowing only will be suitable when at least $60 \%$ of crop evapotranspiration could be supplied during the establishment phase in more than $50 \%$ of the years. When such conditions are not achieved the date is considered unsuitable. Water demand probability was determinate using the crop water balance model based on the method proposed by Thornthwaite \& Mather (1955).

Step 3 - Actual yield and its probability of occurrence: The soybean yield estimates were based on simulations done by the following crop models: FAO Agroecological zone model for estimating potential yield (Yp) (Pereira et al., 2002) and yield depletion by water deficit model for attainable yield (Ya) (Doorenbos \& Kassam, 1979). Yp was estimated considering the interaction between the genotype, solar radiation, photoperiod and air temperature, through the following equation (Pereira et al., 2002):

$$
\mathrm{Yp}=\sum_{\mathrm{i}=1}^{\mathrm{m}} \mathrm{GP} \times \mathrm{C}_{\mathrm{LAI}} \times \mathrm{C}_{\mathrm{RESP}} \times \mathrm{C}_{\mathrm{H}} \times\left(1-\mathrm{C}_{\mathrm{w}}\right)^{-1}
$$

where:

Yp - $\mathrm{kg} \mathrm{ha}^{-1}$

GP - gross photosynthesis, $k g \mathrm{DM} \mathrm{ha}^{-1} \mathrm{~d}^{-1}$

$\mathrm{C}_{\mathrm{LAI}}$ - depletion coefficient to leaf area index (LAI)

$\mathrm{C}_{\mathrm{RESP}}$ - depletion coefficient associated to the maintenance respiration process (function of the air temperature)

$\mathrm{C}_{\mathrm{H}}$ - crop harvest index

$\mathrm{C}_{\mathrm{w}}$ - water content in the harvested part of the plant

' $\mathrm{i}$ ' - day in the crop cycle; and ' $m$ ' is the total of days of the crop cycle, from sowing to harvesting.

After determining Yp, Ya was estimated by the depletion of Yp by the negative effect of water deficit on crop growth, with the equation presented by Doorenbos \& Kassam (1979):

$$
\mathrm{Ya}=\mathrm{Yp} \times \prod_{\mathrm{i}=1}^{\mathrm{n}}\left[1-\mathrm{Ky}_{\mathrm{i}} \times\left(1-\frac{\mathrm{ETa}_{\mathrm{i}}}{\mathrm{ETc}_{\mathrm{i}}}\right)\right]
$$

where:

Ya $-\mathrm{kg} \mathrm{ha}^{-1}$

$\mathrm{Ky}_{\mathrm{i}}$ - water deficit sensitivity index for each phenological phase ' $i$ ': establishment (S-V2), vegetative growth (V2-R1), flowering/yield formation (R1-R5) and full grain/maturity (R6R8)

ETa - actual evapotranspiration, determined by the crop water balance (Thorthwaite \& Mather, 1955) for each 'i' phase

ETc - maximum crop evapotranspiration, which is the product of reference evapotranspiration and crop coefficient $(k c)$ for each ' $i$ ' phase of the crop. 
FAO - Agroecological zone model uses few crop parameters, which makes the calibration process easier, being an advantage in relation to other crop yield models. The main crop variables to be considered to differentiate cultivars are cycle, leaf area index, harvest index and drought tolerance (Andrioli \& Sentelhas, 2009).

Attainable yield was estimated for all sowing dates classified as suitable, according to the extreme air temperature and soil water availability criteria. Crop yield was estimated considering soybean cycle of 120 days and cultivars with high, medium and low drought tolerance, with Ky values for flowering/yield formation (R1-R5) phase, respectively, of $0.78,0.88$ and 0.97 (Battisti, 2013). For the case studies, only the crop cycle of 120 days between sowing and maturity was simulated. The results were compared with the MAPA agroclimatic risk zoning, with the same cycle, soil condition and locations.

Weather data to simulate yield were obtained from the National Institute of Meteorology (INMET) and from the National Water Agency (ANA) in a daily time-scale, being rainfall $(\mathrm{R})$, mean air temperature $(\mathrm{T})$ and sunshine hours (n). The weather data series were obtained for the period between 1980 and 2012 for all locations, totaling 32 crop seasons, with exception only for Cruz Alta, RS, where data from 4 years were missing.

Step 4 - Production cost and soybean price: In agricultural systems is important to evaluate the net income from the crop, since sometimes, maximum yield does not represent maximum net income. Therefore, the best sowing dates should be the ones when net incomes are positive. Production costs can be obtained from different agencies or estimated by the farmers, considering costs with machine, seed, fertilizer, agrochemicals and those with transportation, grain storage, insurance, depreciation, technical assistance and others.

Production costs and prices paid for soybean were obtained from CONAB (2013), for the years between 2007 and 2012. Crop yield can be estimated for a long series by crop models, and it can be converted to monetary value to be compared to costs or vice-versa. With production costs and crop prices is possible to identify how much grain yield is necessary to overcome costs, and identify which sowing dates are the most profitable in terms of the probability of grain yield overcome costs, based on a historical yield series.

Step 5 - Mean air temperature for crop development: Sowing dates are considered suitable when the mean air temperature during all crop phases is between 20 and $30^{\circ} \mathrm{C}$ (Farias et al., 2009 ), that is the ideal range for soybean growth. Sowing dates are considered as marginal when average temperature is lower than $20^{\circ} \mathrm{C}$ or greater than $30^{\circ} \mathrm{C}$. The sowing dates are considered as unsuitable just when extreme temperatures occur, as presented in step (1).

Step 6 - Sowing dates suitability: Sowing dates are considered suitable, marginal or unsuitable depending on the combination of the conditions previously described (Figure 1). Sowing dates are considered suitable when extreme air temperatures are not observed in more than $80 \%$ of the years (Step 1), available soil water for sowing is high enough (Step 2), and estimated crop yield overcome production costs (Step 4) in more than $80 \%$ of the years, and historical mean air temperature is between 20 and $30^{\circ} \mathrm{C}$ during all crop cycle (Step 5). The sowing dates are considered as marginal when extreme air temperatures are observed in less than $20 \%$ of the years, there is available soil water for sowing in more than $50 \%$ of the years, and crop yield overcome production costs between 60 and $80 \%$ of the years, and/or average air temperature along the cycle is lower than $20{ }^{\circ} \mathrm{C}$ or greater than $30{ }^{\circ} \mathrm{C}$. Sowing dates are considered as unsuitable when extreme air temperatures are observed in more than $20 \%$ of the years, or unavailable soil water for sowing is observed, or estimated actual yield is below production costs in more than $40 \%$ of the years.

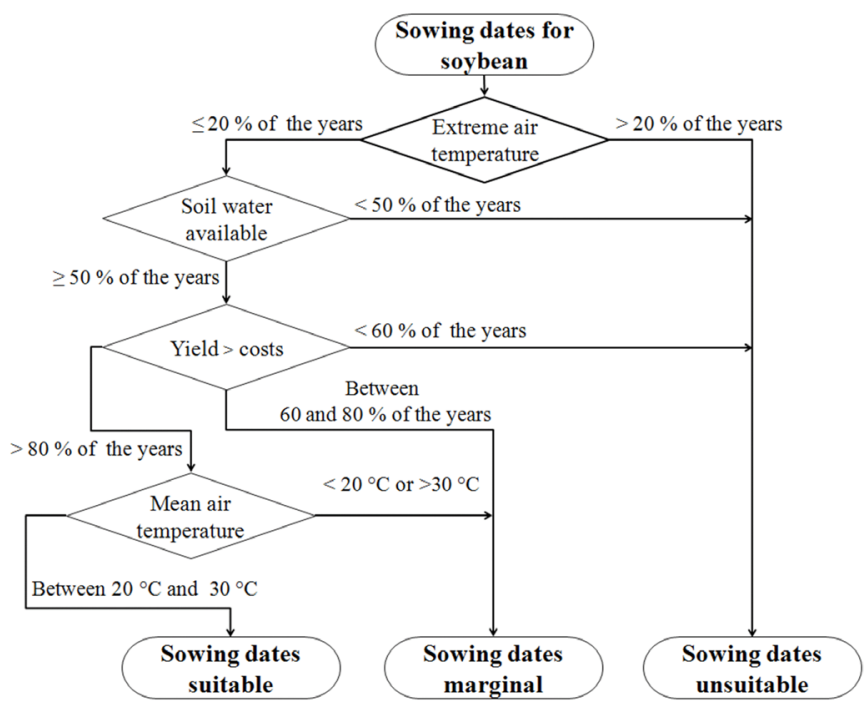

Figure 1. Summary of the conditions for classifying the soybean sowing dates as suitable, marginal and unsuitable, based on extreme air temperatures, soil water availability, actual yield, net income and mean air temperature

The proposed method was applied to classify the soybean sowing dates as suitable, marginal and unsuitable for Cruz Alta, Rio Grande do Sul state, Jataí, Goiás state, and Balsas, Maranhão state, localized respectively in South, Midwest and Northeast regions of Brazil. These locations have different climatic conditions (Table 1) and are important soybean producing regions. The results from the new approach were compared with soybean sowing dates recommended by the agroclimatic risk zoning developed by MAPA.

\section{Results AND Discussion}

The first step to classify the sowing dates was by defining the probability of extreme air temperature for each sowing date. The probability of maximum air temperature above $40{ }^{\circ} \mathrm{C}$ in more than $20 \%$ of the years was not observed in the locations (data not shown). On the other hand, extreme minimum air temperature was observed in Cruz Alta and Jataí, but only in Cruz Alta it was recorded above the threshold of $20 \%$ of the years, limiting soybean sowing between 11/Mar and 01/ 
Table 1. Monthly average maximum and minimum air temperature, sunshine hours and rainfall for Cruz Alta, RS, Jataí, GO, and Balsas, MA, Brazil1

\begin{tabular}{|c|c|c|c|c|c|c|c|c|c|c|c|c|c|}
\hline \multirow{2}{*}{\multicolumn{2}{|c|}{ Location and variable }} & \multicolumn{12}{|c|}{ Month } \\
\hline & & Jan & Feb & Mar & Apr & May & Jun & Jul & Aug & Sept & Oct & Nov & Dec \\
\hline Air temperature maximum & ${ }^{\circ} \mathrm{C}$ & 29.8 & 28.9 & 28.4 & 25.6 & 21.6 & 19.2 & 18.8 & 21.2 & 21.8 & 25.0 & 27.7 & 29.7 \\
\hline Sunshine & Hours per day & 8.1 & 7.5 & 7.5 & 6.4 & 5.7 & 4.5 & 5.2 & 5.8 & 5.8 & 6.6 & 7.9 & 8.3 \\
\hline Rainfall & $\mathrm{mm}$ & 153.0 & 147.0 & 125.0 & 167.0 & 157.0 & 143.0 & 154.0 & 138.0 & 179.0 & 215.0 & 172.0 & 136.0 \\
\hline \multicolumn{14}{|l|}{ Jataí, G0 } \\
\hline Sunshine & Hours per day & 4.7 & 5.2 & 5.4 & 6.9 & 7.3 & 7.6 & 7.9 & 7.7 & 6.0 & 5.9 & 5.7 & 4.9 \\
\hline Rainfall & $\mathrm{mm}$ & 266.0 & 238.0 & 273.0 & 113.0 & 48.0 & 20.0 & 8.0 & 24.0 & 62.0 & 133.0 & 189.0 & 278.0 \\
\hline \multicolumn{14}{|l|}{ Balsas, MA } \\
\hline Air temperature maximum & ${ }^{\circ} \mathrm{C}$ & 30.9 & 31.1 & 31.2 & 31.7 & 32.5 & 33.0 & 33.5 & 34.8 & 35.3 & 33.8 & 32.0 & 31.0 \\
\hline Air temperature minimum & ${ }^{\circ} \mathrm{C}$ & 21.9 & 22.0 & 22.2 & 22.4 & 21.7 & 20.3 & 19.6 & 20.9 & 22.1 & 22.7 & 22.2 & 22.0 \\
\hline Sunshine & Hours per day & 4.6 & 4.7 & 5.1 & 6.3 & 7.8 & 9.0 & 9.4 & 9.5 & 8.2 & 6.1 & 5.0 & 4.4 \\
\hline
\end{tabular}

1The period considered were between 1980 and 2012, totaling 32 years for Jataí, GO, and Balsas, MA, and 28 years for Cruz Alta, RS

Aug (Table 2). Balsas had no records of extreme minimum air temperature since it is located in the north of the country, close to equator line. When the soybean is sown lately and growth occurs in less favorable conditions, as under cooler days, soybean crop has its yield reduced at a rate of $56 \mathrm{~kg} \mathrm{ha}^{-1}$ per day of delay in the sowing date after $25^{\text {th }}$ December in the southern Pampa (Calviño et al., 2003; Monzon et al., 2007).

The next step was to assess the water availability for sowing, where the threshold is at least $50 \%$ of the years with more than $60 \%$ of relative evapotranspiration during the crop establishment phase. Cruz Alta had no limitations of water availability for soybean sowing in all dates of the year (Table 3). Jataí and Balsas had no soil water availability for sowing during the dry period, which occurred mainly during the winter.
The dry period limited the soybean sowing dates in these two locations, between 21/Apr and 11/Sept in Jataí, and 01/May and 11/Oct in Balsas (Table 3). Under dry soil conditions, as well as under low soil temperature, the soybean emergence is very slow, which can expose the seeds to pests and diseases, reducing plant population (EMBRAPA, 2011).

The results show that the limitations to start the soybean sowing is related to the minimum air temperature in Cruz Alta, RS, while in Jataí, GO, and Balsas, MA, it is associated to the lack of enough available soil water. In Cruz Alta, the air temperature can affect plant emergence, which will be longer. In Jataí and Balsas, available water defines the beginning of the sowing period, which is only possible after the first effective rainfalls. However, the early or late soybean sowing has been

Table 2. Percentage of years with extreme minimum air temperature below $1{ }^{\circ} \mathrm{C}$ in Cruz Alta, RS, and Jataí, GO, Brazil

\begin{tabular}{|c|c|c|c|c|c|c|c|c|c|c|c|c|c|c|}
\hline \multirow{3}{*}{ Location } & \multicolumn{14}{|c|}{ Percentage } \\
\hline & & & & & & & Sowin & date $^{1}$ & & & & & & \\
\hline & $01 /$ Jan & 11/Jan & 21/jan & $01 / \mathrm{Feb}$ & $11 / \mathrm{Feb}$ & $21 / \mathrm{Feb}$ & $01 / \mathrm{Mar}$ & 11/Mar & $21 / \mathrm{Mar}$ & $01 / \mathrm{Apr}$ & 11/Apr & 21/Apr & 01/May & 11/May \\
\hline Cruz Alta & 0 & 0 & 0 & 0 & 0 & 0 & 4 & 20 & 22 & 41 & 44 & 59 & 67 & 70 \\
\hline Jataí & 0 & 0 & 0 & 0 & 0 & 0 & 0 & 0 & 3 & 3 & 3 & 6 & 9 & 9 \\
\hline & 21/May & 01/Jun & $11 /$ Jun & $21 /$ Jun & $01 / \mathrm{Jul}$ & 11/Jul & 21/Jjul & $01 /$ Aug & 11/Aug & 21/Aug & $01 /$ Sept & $11 /$ Sept & $21 /$ Sept & $01 / 0 \mathrm{ct}$ \\
\hline Cruz Alta & 74 & 74 & 78 & 74 & 74 & 67 & 56 & 33 & 13 & 8 & 8 & 0 & 0 & 0 \\
\hline Jataí & 9 & 9 & 9 & 6 & 6 & 6 & 3 & 0 & 0 & 0 & 0 & 0 & 0 & 0 \\
\hline
\end{tabular}

'Data not shown had no records

Table 3. Percentage of years with enough available soil water for soybean sowing in Cruz Alta, RS, Jataí, GO, and Balsas, MA, Brazil

\begin{tabular}{|c|c|c|c|c|c|c|c|c|c|c|c|c|}
\hline \multirow{3}{*}{ Location } & \multicolumn{12}{|c|}{ Percentage } \\
\hline & \multicolumn{12}{|c|}{ Sowing date } \\
\hline & 01/Jan & 11/Jan & 21/Jan & $01 /$ Feb & 11/Feb & 21/Feb & 01/Mar & 11/Mar & 21/Mar & 01/Apr & 11/Apr & 21/Apr \\
\hline Cruz Alta & 63 & 63 & 78 & 70 & 67 & 63 & 67 & 56 & 63 & 81 & 81 & 85 \\
\hline Jataí & 100 & 100 & 100 & 97 & 97 & 100 & 100 & 100 & 94 & 78 & 72 & 47 \\
\hline \multirow[t]{2}{*}{ Balsas } & 97 & 91 & 84 & 88 & 97 & 81 & 97 & 97 & 97 & 84 & 72 & 53 \\
\hline & 01/May & 11/May & 21/May & $01 /$ Jun & 11/Jun & 21/Jun & 01/Jul & $11 / \mathrm{Jul}$ & $21 / \mathrm{Jul}$ & 01/Aug & 11/Aug & 21/Aug \\
\hline Cruz Alta & 70 & 70 & 85 & 89 & 96 & 100 & 100 & 96 & 89 & 83 & 79 & 83 \\
\hline Jataí & 31 & 25 & 38 & 16 & 9 & 6 & 0 & 0 & 6 & 9 & 9 & 19 \\
\hline \multirow[t]{2}{*}{ Balsas } & 31 & 16 & 3 & 3 & 0 & 0 & 0 & 0 & 0 & 0 & 0 & 0 \\
\hline & 01/Sept & 11/Sept & $21 /$ Sept & $01 / 0$ ct & $11 / 0$ ct & $21 / 0$ ct & $01 /$ Nov & $11 /$ Nov & $21 /$ Nov & $01 /$ Dec & 11/Dec & 21/Dec \\
\hline Cruz Alta & 79 & 92 & 96 & 92 & 79 & 71 & 75 & 63 & 58 & 58 & 71 & 67 \\
\hline Jataí & 31 & 44 & 50 & 66 & 84 & 91 & 91 & 94 & 100 & 97 & 100 & 100 \\
\hline Balsas & 0 & 6 & 16 & 28 & 44 & 63 & 56 & 69 & 81 & 75 & 97 & 97 \\
\hline
\end{tabular}


an alternative strategy for growers in order to have two crop seasons, as soybean-maize, maize-soybean or even soybeansoybean along the main growing season (Meotti et al., 2012) which brings a higher climatic risk for soybean.

Attainable yield was estimated for all the suitable sowing dates, determined according to the previous criteria, shown in Table 4 . The next step was to obtain the production costs for all locations. For Cruz Alta, Jataí and Balsas, the yield should be respectively more than 2,000,2,500 and 2,000 $\mathrm{kg} \mathrm{ha}^{-1}$ to cover the production costs. It is important to highlight here that production costs and price paid for soybean can vary among farms, regions and seasons of the year, and also between transgenic and conventional soybean cultivars, as showed by Furlaneto et al. (2008). Production costs and price paid for soybean bags are important aspects to be considered in the definition of the soybean sowing dates due to the substantial diferences of them among the Brazilian regions.

The percentage of years with yield covering the production costs is shown in Table 5 for each soybean sowing date for different drought tolerant cultivars for Cruz Alta, Jataí and Balsas. Low probability was observed during January, 21/Feb and 01/Mar in Cruz Alta. In Jataí and Balsas such probability was drastically reduced in January and early February, respectively, which is due to the lower soil water availability to crop growth. Cruz et al. (2010), in the western region of Bahia state, also observed drastic reduction of soybean yield when sowing was performed after the end of December, which is associated to the reduction of rainfall along the crop cycle.

Following to the last step, average air temperature during crop cycle was evaluated. In Cruz Alta, average air temperatures out of the best interval were observed between 21/Apr and 21/ Oct. These results show that when soybeans is grown under low air temperature there are reductions in grain yield as observed by Meotti et al. (2012) in São Domingos, SC, where the sowing dates of 15/Dec and 15/Jan had lower soybean yields than sowing dates of $15 /$ Oct and $15 / \mathrm{Nov}$, due to the cooler temperatures in the last half of the cycle. In Palotina, PR, Dallacort et al. (2008) also observed such yield decrease for the later sowing dates. For Jataí and Balsas, average air temperature is normally within the favorable conditions between 20 and $30^{\circ} \mathrm{C}$ during the crop cycle for all sowing dates (data not shown), which means that thermal conditions are totally suitable for soybean growth and development.

After finishing all steps presented in Figure 1, Cruz Alta had suitable soybean sowing dates between 01/Nov and 11/ Dec, except in 01/Dec for high drought tolerant group cultivars, when it was marginal (Table 6). Bonato et al. (1998) found, based on three field experiments in five locations of Rio Grande do Sul state, that the better sowing window for medium soybean cultivars is November, similar to the results obtained in this

Table 4. Suitable $(\mathrm{S})$ and unsuitable $(U)$ soybean sowing dates according to extreme air temperature and soil water availability in Cruz Alta, RS, Jataí, GO, and Balsas, MA, Brazil

\begin{tabular}{|c|c|c|c|c|c|c|c|c|c|c|c|c|}
\hline \multirow{2}{*}{ Location } & \multicolumn{12}{|c|}{ Sowing date } \\
\hline & 01/Jan & 11/Jan & 21/Jan & 01/Feb & 11/Feb & 21/Feb & 01/Mar & 11/Mar & 21/Mar & $01 / A p r$ & 11/Apr & $21 / \mathrm{Apr}$ \\
\hline Cruz Alta & S & S & S & S & S & S & S & U & U & U & U & U \\
\hline Jataí & S & S & S & S & S & S & S & S & S & S & S & U \\
\hline \multirow[t]{2}{*}{ Balsas } & S & S & S & S & S & S & S & S & S & S & S & S \\
\hline & 01/May & 11/May & 21/May & 01/Jun & $11 /$ Jun & 21/Jun & $01 / \mathrm{Jul}$ & $11 / \mathrm{Jul}$ & $21 / \mathrm{Jul}$ & 01/Aug & 11/Aug & 21/Aug \\
\hline Cruz Alta & U & U & U & U & U & U & U & U & U & U & S & S \\
\hline Jataí & U & U & U & U & U & U & U & U & U & U & U & U \\
\hline \multirow[t]{2}{*}{ Balsas } & $\mathrm{U}$ & U & U & U & U & U & U & U & U & $\mathrm{U}$ & U & U \\
\hline & $01 /$ Sept & 11/Sept & 21/Sept & $01 / 0 \mathrm{ct}$ & $11 / 0$ ct & $21 / 0 \mathrm{ct}$ & $01 /$ Nov & $11 /$ Nov & $21 /$ Nov & 01/Dec & 11/Dec & 21/Dec \\
\hline Cruz Alta & S & $S$ & S & S & $S$ & $S$ & S & S & S & S & S & S \\
\hline Jataí & U & U & S & S & S & S & $S$ & $S$ & $S$ & S & S & $S$ \\
\hline Balsas & U & U & U & U & U & S & S & S & S & S & S & S \\
\hline
\end{tabular}

Table 5. Percentage of years with soybean yield greater than production costs for cultivars with different levels of drought tolerance in Cruz Alta, RS, Jataí, GO, and Balsas, MA Brazil

\begin{tabular}{|c|c|c|c|c|c|c|c|c|c|c|c|c|c|c|c|c|c|c|c|c|c|c|}
\hline \multirow{4}{*}{$\begin{array}{c}\text { Location/ } \\
\text { DT }\end{array}$} & \multicolumn{22}{|c|}{ Percentage } \\
\hline & \multicolumn{22}{|c|}{ Sowing dates } \\
\hline & \multicolumn{3}{|c|}{ Aug } & \multicolumn{3}{|c|}{ Sept } & \multicolumn{3}{|c|}{ Oct } & \multicolumn{3}{|c|}{ Nov } & \multicolumn{3}{|c|}{ Dec } & \multicolumn{3}{|c|}{ Jan } & \multicolumn{3}{|c|}{ Feb } & Mar \\
\hline & 01 & 11 & 21 & 01 & 11 & 21 & 01 & 11 & 21 & 01 & 11 & 21 & 01 & 11 & 21 & 01 & 11 & 21 & 01 & 11 & 21 & 01 \\
\hline \multicolumn{23}{|c|}{ Cruz Alta, RS } \\
\hline High & - & 96 & 96 & 83 & 83 & 88 & 88 & 88 & 92 & 92 & 92 & 96 & 88 & 92 & 88 & 78 & 70 & 67 & 81 & 81 & 63 & 56 \\
\hline Medium & - & 92 & 92 & 83 & 83 & 83 & 88 & 88 & 92 & 92 & 92 & 96 & 83 & 92 & 88 & 74 & 70 & 63 & 85 & 81 & 63 & 56 \\
\hline \multirow[t]{3}{*}{ Less } & - & 92 & 84 & 83 & 79 & 83 & 83 & 83 & 83 & 83 & 92 & 96 & 79 & 83 & 88 & 67 & 67 & 63 & 81 & 81 & 63 & 56 \\
\hline & Sept & & Oct & & & Nov & & & Dec & & & Jan & & & Feb & & & Mar & & & Apr & \\
\hline & 21 & 01 & 11 & 21 & 01 & 11 & 21 & 01 & 11 & 21 & 01 & 11 & 21 & 01 & 11 & 21 & 01 & 11 & 21 & 01 & 11 & 21 \\
\hline \multicolumn{23}{|l|}{ Jataí, G0 } \\
\hline High & 97 & 97 & 100 & 100 & 100 & 100 & 100 & 100 & 100 & 100 & 100 & 100 & 88 & 59 & 25 & 9 & 0 & 0 & 3 & 0 & 0 & - \\
\hline Medium & 97 & 100 & 100 & 100 & 100 & 100 & 100 & 100 & 100 & 100 & 100 & 100 & 94 & 59 & 34 & 13 & 3 & 3 & 3 & 0 & 0 & - \\
\hline Less & 97 & 97 & 100 & 100 & 100 & 100 & 100 & 100 & 100 & 100 & 100 & 100 & 94 & 66 & 38 & 19 & 6 & 6 & 3 & 0 & 0 & - \\
\hline \multicolumn{23}{|c|}{ Balsas, MA } \\
\hline High & - & - & 100 & 100 & 100 & 94 & 94 & 97 & 100 & 100 & 97 & 100 & 97 & 91 & 78 & 53 & 38 & 19 & 9 & 0 & 0 & 0 \\
\hline Medium & - & - & 100 & 100 & 100 & 94 & 94 & 97 & 100 & 97 & 97 & 97 & 97 & 88 & 75 & 50 & 34 & 16 & 3 & 0 & 0 & 0 \\
\hline Less & - & - & 100 & 100 & 97 & 94 & 94 & 97 & 97 & 97 & 97 & 97 & 97 & 88 & 69 & 44 & 28 & 13 & 3 & 0 & 0 & 0 \\
\hline
\end{tabular}


Table 6. Soybean sowing dates suitability in Cruz Alta, RS, Jataí, GO, and Balsas, MA, Brazi, considering cultivars with different drought tolerances, climate limitations, crop yield and net income

\begin{tabular}{|c|c|c|c|c|c|c|c|c|c|c|c|c|c|c|c|c|c|c|c|c|c|c|}
\hline \multirow[b]{2}{*}{ DT } & \multicolumn{22}{|c|}{ Sowing dates ${ }^{1,2}$} \\
\hline & \multicolumn{3}{|c|}{ Aug } & \multicolumn{3}{|c|}{ Sept } & \multicolumn{3}{|c|}{ Oct } & \multicolumn{3}{|c|}{ Nov } & \multicolumn{3}{|c|}{ Dec } & \multicolumn{3}{|c|}{ Jan } & \multicolumn{3}{|c|}{ Feb } & $\begin{array}{c}\text { Mar } \\
01\end{array}$ \\
\hline \multicolumn{23}{|c|}{ Cruz Alta, RS } \\
\hline Medium & $U$ & M & M & M & M & M & $M$ & M & M & $S$ & S & S & $S$ & S & $\mathrm{M}$ & $M$ & $\mathrm{M}$ & M & M & M & M & $U$ \\
\hline \multirow[t]{2}{*}{ Less } & U & M & $\mathrm{M}$ & M & M & $\mathrm{M}$ & $\mathrm{M}$ & $\mathrm{M}$ & $\mathrm{M}$ & $S$ & $S$ & $S$ & $S$ & $S$ & $\mathrm{M}$ & $\mathrm{M}$ & $\mathrm{M}$ & $\mathrm{M}$ & $\mathrm{M}$ & $\mathrm{M}$ & $\mathrm{M}$ & U \\
\hline & \multicolumn{2}{|l|}{ Sept } & \multicolumn{2}{|c|}{ Oct } & \multicolumn{3}{|c|}{ Nov } & \multicolumn{3}{|c|}{ Dec } & \multicolumn{3}{|c|}{ Jan } & \multicolumn{3}{|c|}{ Feb } & \multicolumn{3}{|c|}{ Mar } & \multicolumn{3}{|c|}{ Apr } \\
\hline High & S & S & S & S & $S$ & S & $S$ & S & S & $S$ & $S$ & S & S & M & $U$ & $U$ & $U$ & $U$ & U & U & U & U \\
\hline Medium & $S$ & $S$ & S & S & S & S & $S$ & S & S & $S$ & $S$ & S & $S$ & $U$ & U & $U$ & U & $U$ & U & U & U & $U$ \\
\hline Less & S & S & S & S & S & S & $S$ & S & $S$ & $S$ & $S$ & $S$ & $S$ & U & U & U & U & U & U & U & U & U \\
\hline \multicolumn{23}{|c|}{ Balsas, MA } \\
\hline High & U & U & U & U & S & S & $S$ & S & S & $S$ & $S$ & S & S & S & $\mathrm{M}$ & U & $U$ & $U$ & U & U & U & U \\
\hline Medium & U & U & U & U & $S$ & $S$ & $S$ & $S$ & $S$ & $S$ & $S$ & $S$ & $S$ & $S$ & $\mathrm{M}$ & U & $U$ & $U$ & U & U & U & U \\
\hline
\end{tabular}

1 Dates not show are unsuitable.

$2 \mathrm{U}$ (unsuitable), M (marginal) and S (suitable)

study. For Dourados, MS, Fietz \& Rangel (2008) observed the same, which is caused by the best interaction between photoperiod and water deficit.

Cruz Alta presented marginal suitability for soybean sowing from $11 /$ Aug to $21 /$ Oct and from $21 / \mathrm{Dec}$ to $21 / \mathrm{Feb}$, which is associated to the average air temperature out of $20-30{ }^{\circ} \mathrm{C}$ interval. The soybean sowing during these periods can bring undesirable consequences for crop, such as early flowering, short stature and low grain yield (Sinclair et al., 2005; Meotti et al., 2012). These proposed soybean sowing dates are different from those recommended by MAPA for marginal period, however, the suitable dates are similar, starting from $21 / \mathrm{Oct}$ to $21 / \mathrm{Dec}$. The main difference between the proposed methodology and with the one recommended by MAPA is the possibility of anticipating the sowing to August and September. Also, the new approach enables to identify which factor is limiting the sowing in a given date, helping to choose alternative practices. The weather conditions which classify the early sowing dates as marginal is the low air temperature, but in years in which soil temperature is greater than historical mean, it is possible to anticipate the soybean sowing and thus to have two successive crop seansons, like soybean in the main season and maize as a second season.

In Jataí the sowing dates were suitable between $21 /$ Sept and 21/Jan for all cultivars, while between 01/Feb and 11/Apr the conditions were unsuitable, except for less drought tolerant cultivar that has $01 / \mathrm{Feb}$ classified as marginal (Table 6). The sowing dates recommended by this procedure is different from those recommended by MAPA, which considers as suitable the sowing dates between 01/Oct and 21/Dec. The differences between the two methodologies is caused by the use of potential and attainable yields, production costs and other limiting weather conditions in the new procedure. When comparing the new approach with MAPA methodology, Jatai had a longer sowing window, showing that even occuring water deficit, that classified January like unsuitable by MAPA, estimated yield was greater than production costs.

Balsas had suitable sowing period between 01/Nov and $01 /$ Feb for all cultivars (Table 6), which is very similar to the period recommended by MAPA, between 21/Oct and 11/ Feb. However, the present procedure shows that $11 / \mathrm{Feb}$ was marginal for all cultivars. Based on that, it is clear that Balsas had a reduction of the sowing window when compared with MAPA recommendation, opposite behavior to that found for Cruz Alta, RS, and Jataí, GO, which showed a longer period than recommended by MAPA recommendation. In the beginning of the sowing window $(21 / \mathrm{Oct})$, this operation was limited by the low soil water availability, condition not considered by MAPA, whereas in the end of the sowing window $(11 / \mathrm{Feb})$ the new approach considered a marginal condition due to the drastic reduction in the actual yield, reducing the probability of the yield to be greater than production costs. At these early or late sowing dates it would be important to consider the irrigation as a management procedure for reducing the risks in this region.

The longer suitable soybean sowing window, from 21/Sept to $21 / \mathrm{Jan}$, in Jataí and, from $01 / \mathrm{Nov}$ to $01 / \mathrm{Feb}$, in Balsas, just can be a fact if the cultivars have an appropriate adaptation of juvenile period and photoperiod, which will help to increase the cycle and grain weight (Sinclair et al., 2005). According to Lima et al. (2000), the cultivars more adapted for such longer sowing window are those with longer juvenile period.

It is important to highlight that this approach need much more information and need to be defined at the farm level, since it considers information about production costs, regional soybean price and cultivar characteristics to estimate yield. About the yield estimate, many studies have been developed in Brazil, calibrating and evaluating crop models for different crops, cultivars and regions. By this way, the new approach can be applied for different soybean production regions for defining with more details the better sowing dates, increasing yield and reducing yield gaps.

\section{Conclusions}

1. The procedures proposed by this study can generate more accurate information to support soybean sowing dates 
recommendation, minimizing yield losses from climatic risk and increasing economic profits;

2. The new approach showed potentiality to define sowing dates, by considering agronomic and economic aspects of the crop, differing from MAPA's methodology, mainly in the beginning and end of the sowing window;

3. Farmers can improve agricultural planning choosing the best sowing dates through this new approach, reducing soybean yield gap.

\section{Literature Cited}

Anapalli, S. S.; Ma, L.; Nielsen, D. C.; Vigil M. F.; Ahuja, L. R. Simulating planting date effects on corn production using RZWQM and CERES- Maize models. Agronomy Journal, v.97, p.58-71, 2005.

Andrioli, K. G.; Sentelhas, P. C. Brazilian maize genotypes sensitivity to water deficit estimated through a simple crop yield model. Pesquisa Agropecuária Brasileira, v.44, p.653660, 2009.

Bastidas, A. M.; Setiyona, T. D.; Dobermann, A.; Cassman, K. G. Soybean sowing date: The vegetative, reproductive, and agronomic impacts. Crop Science, v.48, p.727-740, 2008.

Battisti, R. Épocas de semeadura da cultura da soja com base no risco climático e na rentabilidade líquida para as principais regiões produtoras do Brasil. Piracicaba: ESALQ/USP, 2013. 261p. Dissertação Mestrado

Battisti, R.; Sentelhas, P. C.; Pilau, F. G.; Wollmann, C. A. Eficiência climática para as culturas da soja e do trigo no estado do Rio Grande do Sul em diferentes datas de semeadura. Ciência Rural, v.43, p.390-396, 2013.

Bonato, E. R.; Bertagnolli, P. F.; Ignaczak, J. C.; Tragnaco, J. L.; Rubin, S. A. L. Desempenho de cultivares de soja em três épocas de semeadura no Rio Grande do Sul. Pesquisa Agropecuária Brasileira, v.33, p.879-884, 1998.

Calviño, P. A.; Sadras, V. O.; Andrade, F. H. Development, growth and yield of late-sown soybean in the southern Pampas. European Journal Agronomy, v.19, p.265-275, 2003.

Chen, G. H.; Wiatrak, P. Soybean development and yield are influenced by planting date and environmental conditions in the southeastern coastal plain, United States. Agronomy Journal, v.102, p.1731-1737, 2010.

CONAB - Companhia Nacional de Abastecimento. Produtos e serviços. <http://www.conab.gov.br/>. 5 Fev. 2013.

Cruz, T. V.; Peixoto, C. P.; Martins, M. C. Crescimento e produtividade de soja em diferentes épocas de semeadura no oeste da Bahia. Scientia Agraria, v.11,p.33-42, 2010.

Dallacort, R.; Freitas, P. S. L. de; Gonçalves, A. C. A.; Faria, R. T. de; Rezende, R.; Bertonha, A. Níveis de probabilidade de rendimento de quatro cultivares de soja em cinco datas de semeadura. Acta Scientiarum Agronomy, v.30, p.261-266, 2008.
Doorenbos, J.; Kassam, A. M. Yield response to water. Rome: FAO, 1979. 300p. Irrigation and Drainage Paper, n.33

Egli, D. B.; Cornelius, P. L. A regional analysis of the response of soybean yield to planting date. Agronomy Journal, v.101, p.330-335, 2009.

EMBRAPA - Empresa Brasileira de Pesquisa Agropecuária. Tecnologia de produção de soja - Região central do Brasil 2012 e 2013. Londrina: Embrapa Soja, 2011. 264p. Sistema de Produção n.15

Farias, J. R. B.; Assad, E. D.; Almeida, I. E. de; Evangelista, B. A.; Lazzarotto, C.; Neumaier, N.; Nepomuceno, A. L. Caracterização de risco de déficit hídrico nas regiões produtoras de soja no Brasil. Revista Brasileira de Agrometeorologia, v.9, p.415-421, 2001.

Farias, J. R. B.; Neumaier, N.; Nepomuceno, A. L. Soja. In: Monteiro, J. E. B. A. Agrometeorologia dos cultivos: O fator meteorológico na produção agrícola. Brasília: INMET, 2009. cap.15, p.261-278.

Fietz, C. R.; Rangel, M. A. S. Época de semeadura da soja para a região de Dourados - MS, com base na deficiência hídrica e no fotoperíodo. Engenharia Agrícola, v.28, p.666672, 2008.

Furlanetto, F. P. B.; Reco, P. C.; Kanthack, R. A. D.; Esperancini, M. S. T.; Ojima, A. L. R. O. Soja transgênica versus convencional: estimativa dos custos operacionais de produção na região do Médio Paranapanema, Estado de São Paulo. Ciência Agrotécnica, v.32, p.1935-1940, 2008.

Han, T. F.; Wu, C. X.; Tong, Z.; Mentreddy, R. S.; Tan, K. H.; Gai, J.Y. Postflowering photoperiod regulates vegetative growth and reproductive development of soybean. Environmental and Experimental Botany, v.55, p.120-129, 2006.

$\mathrm{Hu}, \mathrm{M}$.; Wiatrak, P. Effect of planting date on soybean growth, yield, and grain quality: Review. Agronomy Journal, v.104, p.785-790, 2012.

Kumudini, S. V.; Pallikonda, P. K.; Steele, C. Photoperiod and e-genes influence the duration of the reproductive phase in soybean. Crop Science, v.47, p.1510-1517, 2007.

Lima, W. F.; Toledo, J. F. F. de; Arias, C. A. A.; Oliveira, M. F. de. Stability of soybean yield through different sowing periods. Pesquisa Agropecuária Brasileira, v.35, p.2181-2189, 2000.

MAPA - Ministério da Agricultura, Pecuária e Abastecimento. Zoneamento Agrícola. http://www.agricultura.gov. br/politica-agricola/zoneamento-agricola/portariassegmentadas-por-uf. 31 Jul. 2012.

Meotti, G. V.; Benin, G.; Silva, R. R.; Beche, E.; Mumaro, L. B. Épocas de semeadura e desempenho agronômico de cultivares de soja. Pesquisa Agropecuária Brasileira, v.47, p.14-21, 2012.

Monzon, J. P.; Sadras, V. O.; Abbate, P. A.; Caviglia, O. P. Modelling management strategies for wheat-soybean double crops in the south-eastern Pampas. Field Crops Research, v.101, p.44-52, 2007.

Pereira, A. R.; Angelocci, L. R.; Sentelhas, P. C. Agrometeorologia: fundamentos e aplicações práticas. Guaíba: Agropecuária, 2002. 478p. 
Rosenberg, N. J.; Blad, B. L.; Verma, S. B. Microclimate - The biological environment. New York: John Wiley \& Sons, 1983. 495p.

Sinclair, T. R.; Neumaier, N.; Farias, J. R. B.; Nepomuceno, A. L. Comparison of vegetative development in soybean cultivars for low-latitude environments. Field Crops Research, v.92, p.53-59, 2005.
Soler, A. M. T.; Sentelhas, P. C.; Hoogenboom, G. The impact of El Niño Southern Oscillation phases on off-season maize yield for a subtropical region of Brazil. International Journal of Climatology, v.30, p.1056-1066, 2010.

Thornthwaite, C. W.; Mather, J. R. The water balance. Publications in Climatology. Nex Jersey: Drexel Institute of Technology, 1955. 104p. 